\title{
ХИЙЖУУЛЭХ УРВАЛЫН ТЭНЦВЭРИЙН ТОГТМОЛЫГ ТОДОРХОЙЛОХ СУДАЛГАА
}

\author{
А.ТҮмэнбаяр ${ }^{1}$, Б.Авид², Ч.Дашпунцุаг ${ }^{1}$ \\ ${ }^{1}$ ХШУТИС-Эрчим хүчний сургууль \\ ${ }^{2}$ Шинжлэх Ухааны Академи \\ Цахим шууда: tumeе_79@must.edu.mn
}

\section{ХУРААНГУЙ}

НҮҮрсийг хийжүҮлэх прочессын дүнд үҮсэх хийн найрлагад нөлөөлдөг урвалын тэнивэрийн тогтмолыг онолын үндсэн ойлголтоос нь хөөн тайлбарлаж, хатуу түлиийг хийжүүлэх проиессын голлох урвалуудтай холбон, тэдгээрийг илэрхийлэх тэнивэрийн тогтмолыг тодорхойлох арга зүйг судлан Гибссийн энергийн аргыг хийжүүлэлтийн тооцоонд ашиглахад тохиромжтой гэж үзлээ.

Түлхүур үгс: Урвалын тэнивэрийн тогтмол, хийжүүлэлт, хийн найрлага, температур;

\section{ОРШИЛ}

Нүүрсийг хийжүүлэх процесс нь түүнийг халаан дэгдэмхий бодисыг зайлуулах, улмаар үүссэн коксыг (char) исэлдүүлэн $\mathrm{CO}_{2}$ болон $\mathrm{CO}$ үүсгэх зорилготой бөгөөд хийн генераторт явагдах хийжүүлэлтийн процессыг хатаалт, пиролиз, хийжүүлэлт (ангижруулалт, исэлдүүлэлт) ба үнс ба шаарга зайлуулах гэсэн бүсүүдэд хуваадаг. Хийжүүлэх процессыг явуулах нөхцөл, параметр, технологийн онцлогоос хамааруулан дараах байдлаар ангилна. Үүнд:

1. Шатах хийн дулаан гаргах чадвараар, МДж/ $\mathrm{M}^{3}$ : бага дулаан гаргах чадвартай, 4.18-6.7;

2. дундаж дулаан гаргах чадвартай хий 6.7-18.8; өндөр дулаан гаргах чадвартай хий 31-40;
3. Хийн зориулалтаар нь: эрчим хүчний (шууд шатаах), технологийн (нийлэг хий буюу устөрөгч, техникийн нүүрстөрөгчийн үйлдвэрлэл);

4. Түлшний ширхэглэлээр нь: том, нарийн ширхэглэлтэй, тоосон нүүрсний хийжүүлэлт;

5. Үлээх агентийн төрлөөр нь: агаарын, уур-агаарын, хүчилтөрөгчийн, уурхүчилтөрөгчийн, уурын;

6. Эрдэслэг хольцийг ялгах байдлаар нь: нойтон, хуурайгаар үнс зайлуулах, шингэнээр шааргыг зайлуулах;

7. Хийжүүлэлтийн даралтаар нь: атмосферын даралтын 0.1-0.13 МПа, дунд даралтын 2- 3 МПа хүртэл, өндөр даралтын 2 - 3 МПа-аас дээшхи;

8. Түлшний хийжүүлэлтийн үеийн 
хөдөлгөөний төлөвөөр нь: буцламтгай болон хуурмаг шингэрүүлсэн давхаргатай, тоосон нүүрсний урсгалтай;

9. Хийжүүлэлтийн температураар нь: нам температурын $800{ }^{\circ} \mathrm{C}$ хүртэл, дунд температурын $800-1300{ }^{\circ} \mathrm{C}$, өндөр температурын $1300{ }^{\circ} \mathrm{C}$-аaс дээш;

10. Хийжүүлэлтийн процессын дулааны балансаар нь: хатуу, шингэн, хийн түлшний шаталттай дотоод болон гадаад дулааны эх үүсвэртэй гэж ангилдаг [1].

$$
\begin{array}{ll}
2 \mathrm{C}+\mathrm{O}_{2}=2 \mathrm{CO}+218.8 \quad \mathrm{MДж/кмоль} \\
2 \mathrm{C}+\mathrm{O}_{2}=\mathrm{CO}_{2}+394.4 \mathrm{MДж/кмоль}
\end{array}
$$

Эхний ангижруулалтын бүсэд халсан нүүрстөрөгч усны ууртай урвалд орж явагдана.

$$
\begin{array}{ll}
\mathrm{C}+\mathrm{H}_{2} \mathrm{O}=\mathrm{CO}+\mathrm{H}_{2}+132.6 & \text { МДж/кмоль } \\
\mathrm{C}+\mathrm{H}_{2} \mathrm{O}=\mathrm{CO}_{2}+2 \mathrm{H}_{2}-89.5 & \text { МДж/кмоль }
\end{array}
$$

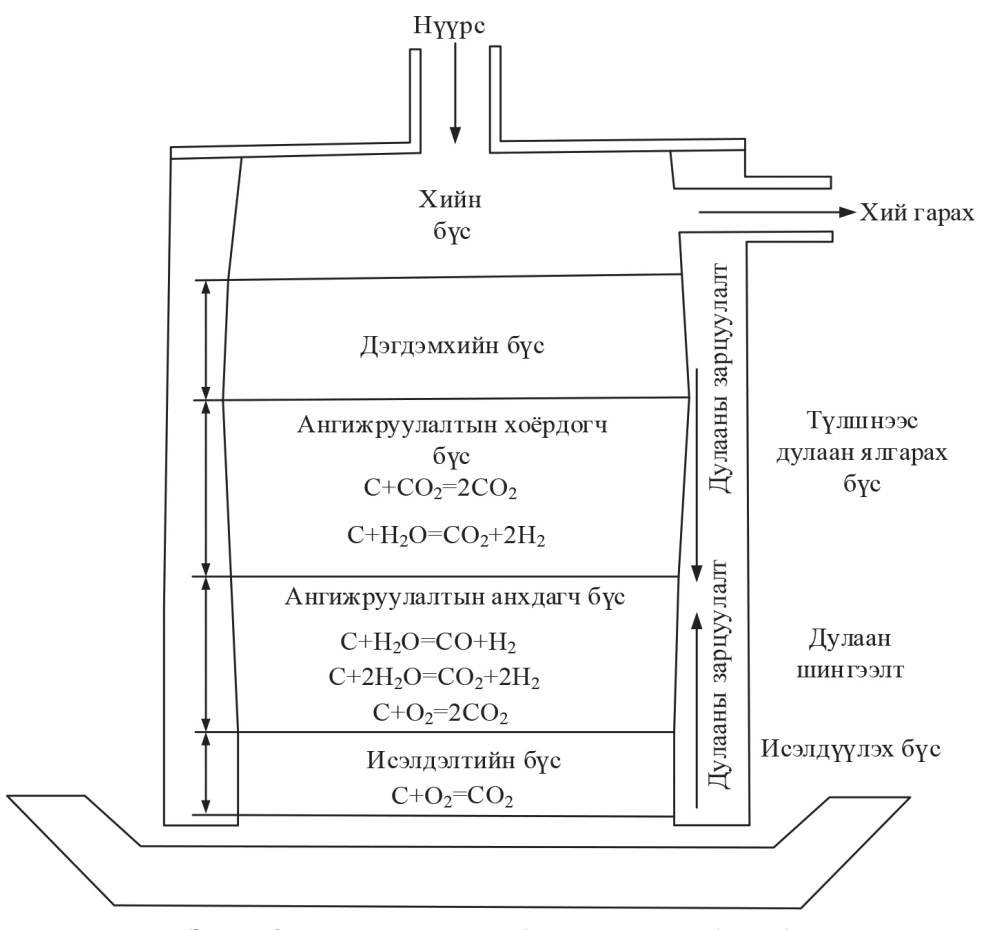

Зураг 1. Хийн генератор дахь урвальюн бүсүуд 
Улмаар хоёр дахь ангижруулалтын бүсэд дараах үндсэн урвалууд явагдана.

$$
\begin{aligned}
& \mathrm{CO}_{2}+\mathrm{C}=2 \mathrm{CO}-175.6 \quad \text { МДж/кмоль } \\
& \mathrm{CO}+\mathrm{H}_{2} \mathrm{O}=\mathrm{CO}_{2}+\mathrm{H}_{2}+43.1 \quad \text { МДж/кмоль }
\end{aligned}
$$

Урвалын тэгшитгэлүүдээс үзэхэд исэлдүүлэлтийн болон ангижруулалтын бүсэд нүүрстөрөгчийн диоксид кокстой урвалд нүүрстөрөгчийн моноксид үүсдэг.

$$
\mathrm{CO}_{2}+\mathrm{C}=2 \mathrm{CO}-175.6 \quad \text { МДж/кмоль }
$$

Нүүрстөрөгчийн монооксид ба устөрөгчийн хоорондох урвал явагдсанаар метан үүсэх ба энэ нь дулааны нөлөөлөлд орж метан задрах процесс болдог.

$$
\begin{aligned}
& \mathrm{CO}+3 \mathrm{H}_{2}=\mathrm{CH}_{4}+\mathrm{H}_{2} \mathrm{O}+203.7 \text { МДж/кмоль } \\
& \mathrm{CH}_{4}=\mathrm{C}+2 \mathrm{H}_{2}-71.1 \text { МДж/кмоль }
\end{aligned}
$$

Хийн генераторт экзотерм ба эндотерм урвалууд явагдах ба Ле Шатальегийн зарчим ёсоор тухайн хэсэг дэх экзотерм урвалын тэнцвэр нь температур өсөхөд энэ хэсэг дэх процесст оролцох материалын бүрдэл рүү, харин тухайн мөчид температур буурахад урвалын бүтээгдэхүүний бүрдэл рүY шилждэг. Ийм маягаар процессын температур, мөн түлш болон бусад исэлдүүлэгчийн харилцан үйлчлэлийн онцлог зэрэг төрөл бүрийн хүчин зүйлсээс хамааруулан $\mathrm{CO} / \mathrm{CO}_{2}$ харьцааг тогтооно.
Дээр өгүүлсэнчлэн шатах хийн найрлага нь 5 үндсэн хэсгээс бүрдэх ба тэдгээрийг олохын тулд 5 үл мэдэгдэгч бүхий тэгшитгэлийг бичиж, шаталтын урвалд оролцож буй бүтээгдэхүүнүүдийн хэмжээг молиор илэрхийлэх ба мөн шаардагдах усны уурын хэмжээг тодорхойлдог. Нэг молекул нүүрстөрөгчөөс нэг молекул СО, эсвэл нэг молекул $\mathrm{CO}_{2}$ бий болох бөгөөд эхний тэгшитгэлээс харахад 5.7 моль нүүрстөрөгчөөс 5.7 моль $\mathrm{CO}$ ба $\mathrm{CO}_{2}$ ҮҮсэж байна.

$$
\mathrm{CO}+\mathrm{CO}_{2}=5.7 \text { моль }
$$

Хоёр дахь тэгшитгэлээр $\mathrm{C}+\mathrm{H}_{2} \mathrm{O}=\mathrm{CO}+\mathrm{H}_{2}$ урвалын дагуу нэг молекул $\mathrm{H}_{2} \mathrm{O}-$ aас нэг молекул устөрөгч $\left(\mathrm{H}_{2}\right)$ үүснэ.

$$
\mathrm{H}_{2}+\mathrm{H}_{2} \mathrm{O}=1.33 \text { моль }
$$

Хийн генераторт явагдах үндсэн өөрчлөгддөг.

тэгшитгэл нь $\mathrm{CO}+\mathrm{H}_{2} \mathrm{O} \Leftrightarrow \mathrm{CO}_{2}+\mathrm{H}_{2}$

Хэрэв агаарт нэг атом хүчилтөрөгчид хэлбэртэй байх ба энэ урвалын тэнцвэрийн тэгшитгэл нь $k=\frac{\mathrm{CO} \cdot \mathrm{H}_{2} \mathrm{O}}{\mathrm{CO}_{2} \cdot \mathrm{H}_{2}} \quad$ (12) болно. 1.9 моль азот ноогддог гэдгээс тооцвол, шаталтын урвалд оролцох нэг моль азотод $\frac{N_{2}}{1.9}$ атом хүчилтөрөгч ноогдож байна.

Энэ тогтмол нь температураас хамаарч 


$$
2 \mathrm{CO}_{2}+\mathrm{CO}=\frac{\mathrm{N}_{2}}{1.9}+\mathrm{H}_{2}
$$

Тав дахь үндсэн тэгшитгэлийг хийн генераторын дулааны балансын тэгшитгэлээс гарган авна [8].

$$
73726 \mathrm{CO}+63286 \mathrm{H}_{2}+5506 \mathrm{~N}_{2}+6500 \mathrm{H}_{2} \mathrm{O}+8321 \mathrm{CO}_{2}=517976
$$

Эдгээр таван тэгшитгэлийг ашиглан урвалын тэнцвэрийн тогтмол “к” хийжүүлэлтийн үеийн температураас

\section{МАТЕРИАЛ, АРГА ЗУЙ}

Химийн урвалд орж байгаа бодисын концентрацаас химийн урвалын хурд хамаарах хамааралдээрүндэслэнНорвегийн эрдэмтэн К.М.Гульдберг болон П.Вааге нар 1867 онд анх масс үйлчлэлийн хуулийг гаргасан бөгөөд түүнийг термодинамикийн

$$
\frac{d \ln K}{d T}=-\frac{Q}{R T^{2}}
$$

Энд: К-урвалын тэнцвэрийн тогтмол; Q- урвалын дулааны эффект; T-үнэмлэхүй температур; R-хийн тогтмол.

$$
\ln K=-\int \frac{Q}{R T^{2}} d T+C
$$

Тэрээр өгөгдсөн температурын үед К-ийн утга өгөгдөхгүй, интегралын тогтмол хэрхэн хамаарахыг судалж тодорхойлохыг зорилоо. талаас нь тооцоолж болохыг Ф.Габер 1907 онд анх нийлмэл аммиакийг гарган авахдаа боловсруулсан байна. Тэрбээр даралт болон эзлэхүүн тогтмол үеийн химийн урвалын тэгшитгэлээс дараах тэнцэтгэлийг гарган авсан байна [8]

15-p тэгшитглийг интеграчилан хувиргавал дараах хэлбэртэй болно.

С өөрчлөгдөхгүй гэж үзээд дараах байдлаар интегралыг тодорхойлсон байна.

$$
\int_{K_{1}}^{K_{2}} d \ln K=\int_{T_{1}}^{T_{2}}-\frac{Q}{R T^{2}} d T=-\frac{Q}{R} \int_{T_{1}}^{T_{2}}-\frac{d T}{T}
$$

Эндээс

$$
\ln \frac{K_{2}}{K_{1}}=\frac{Q}{R}\left(\frac{1}{T_{2}}-\frac{1}{T_{1}}\right)
$$

Дээрх тэгшитгэлд байгаa Q буюу дулааны эффектийн утга нь температураас хамаарна. Үүнийг Кирхгофийн үндсэн

тэгшитглд эмпирикийн тэгшитгэлээр хамааруулан тодорхойлсон байдаг [9].

$$
Q=Q_{0}+\Delta a T+\Delta b T^{2}+\Delta e T^{3}+\ldots
$$


19-р тэгшитгэлийг 16-р тэгшитгэлд орлуулан тавихад тэгшитгэл доорх хэлбэртэй болно.

$$
\ln K=-\int \frac{Q_{0}}{R T} d T+\int \frac{\Delta a}{R T} d T+\int \frac{\Delta b}{2 R} d T+\int \frac{\Delta e T}{3 R} d T+\ldots+C
$$

Дээрх 20-р тэгшитгэлийг интеграчлан хувиргавал Габерын тэгшитгэл гарна [9].

$$
\ln K=\frac{Q_{0}}{R T}+\frac{\Delta a \ln T}{R}+\frac{\Delta b T}{2 R}+\frac{\Delta e T^{2}}{3 R} \ldots+C
$$

Түүнчлэн энд өгүүлж буй урвалын тэнцвэрийн тогтмолыг Гессийн хуульд тулгуурлан Гибсс болон Гельмгольц нарын тодорхойлсон энергийн өөрчлөлтүүдийг ашиглан тодорхойлсон байдаг.

Г.И.Гесс 1840 онд нээсэн термохимийн үндсэн хуулиар урвалын дулааны эффект нь урвал явагдах нөхцөлөөс хамаарахгүй ( $\mathrm{P}=$ const ба $\mathrm{V}=$ const), зөвхөн системийн эхний ба эцсийн төлвөөс хамаарах ба урвалд орж байгаа болон түүнээс үүссэн бодисуудын төлвийг тодорхойлно гэжээ [9].

Ер нь термодинамик талаасаа урвалын тэнцвэрийн тогтмолыг тодорхойлоход

Гиббсийн энерги

$$
\Delta G=\Delta H-T \Delta S
$$

Гельмгольцийн буюу чөлөөт энерги

$$
\Delta F=\Delta U-T \Delta S
$$

түүний гол термодинамикийн тодорхойломж болсон даралт-температур тогтмол үеийн потенциал энерги буюу Гибссийн энерги $(\Delta \mathrm{G})$, эзэлхүүн-температур тогтмол үеийн потенциал энерги буюу Гельмгольцийн энерги $(\Delta \mathrm{F})$ чухал нөлөөтэй байдаг. Өөрөөр хэлбэл урвал тэнцвэрт орох үед $\Delta \mathrm{G}=0, \Delta \mathrm{F}=0$ буюу Гибссийн ба Гельмгольцийн (чөлөөт энерги) энергийн утгууд нь хамгийн бага утгандаа хүрдэг.

Иймд тэнцвэрийн төлөвд орсон системийн хувьд дээрх энергүүдийг дараах байдлаар тодорхойлдог.

Энд: $\Delta \mathrm{S}$-химийн урвалын энтропийн өөрчлөлт,

Практик тооцоонд ихэвчлэн тэнцвэрийн тогтмолыг урвалд орж буй болон урвалаас үүссэн бодисуудын хэсгийн даралтаар (Kp) эсвэл концентрациар (Kc) илэрхийлдэг.

$$
\Delta G_{T}^{0}=-R T \ln K p
$$

Энэ тэгшитгэлээс хэсгийн даралтаар илэрхийлсэн тэнцвэрийн тогтмолыг $\ln K p=-\Delta G_{T}^{0} / R T, \quad$ процесс $\quad \mathrm{V}=\mathrm{const}$ ба $\mathrm{T}=$ const нөхцөлд явагдана гэвэл концентрацаар илэрхийлсэн тэнцвэрийн тогтмолыг
Хэрэв урвалд орж байгаа бүх бодис стандарт төлөвд оршиж байна гэж үзвэл, үүнийг изотерм урвал гэж үзээд тэгшитгэлийг дараах байдлаар бичнэ [9]:

тодорхойлно.

1886 онд Я.Вант-Гофф өөрийн нэрээр нэрлэгдсэн изобар нөхцөлд явагдах урвалын тэнцвэрийн тогтмолыг илэрхийлэх гаргалгааг туршилтаар тодорхойлсон байна [10]. 


$$
\frac{d \ln K^{0}}{d T}=\frac{{ }^{\Delta} H_{T}^{0}}{R T^{2}}
$$

Вант-Гоффийн аргачлалаар тооцоход $\Delta \mathrm{rH}_{\mathrm{T}}^{0}>0$ үед эндотерм урвал явагдаж температур нэмэгдэхэд урвалын тэнцвэрийн тогтмол өсөх ба химийн тэнцвэр урвалын бүтээгдэхүүний талд үйлчлэх ба эсрэг тохиолдолд $\Delta \mathrm{rH}_{\mathrm{T}}^{0}<0$ үед экзотерм урвал явагдаж температур нэмэгдэхэд тэнцвэрийн тогтмол бууран химийн тэнцвэр урвалд орох бодисуудын талд үйлчилнэ. Харин $\Delta \mathrm{rH}^{0}{ }_{\mathrm{T}}=$ 0 үед тэнцвэрийн тогтмол температураас хамаардаггүй байна.
Оросын эрдэмтэн Г.И.Дешалит, С.Д.Бесков болон АНУ-ын эрдэмтэн В.Гумз нар өөрсдийн бүтээлдээ дээр дурьдсан аргачлалуудыг онцлон авч үздэг.

Бид өөрсдийн судалгааны хүрээнд мөн дээр дурьдсан аргуудыг харьцуулан үзэж Гиббсийн энергийн хамгийн бага утгын үеийн тэнцвэрийн тогтмол болон хийжүүлэх урвалын гол урвал болсон $\mathrm{CO}+\mathrm{H}_{2} \mathrm{O} \Leftrightarrow \mathrm{CO}_{2}+\mathrm{H}_{2}$ дээр

$$
\log K_{P}=-36.72508-\frac{3994.704}{T}-4.462408 \cdot 10^{-3} T+0.671814 \cdot 10^{-6} T^{2}+12.220277 \cdot \log T(26)
$$

томъёог ашиглан тооцох аргачлалыг хэрэглэн судалгааны үр дүнг боловсрууллаa [4-7].

\section{ҮР ДУН}

Эхлээд Гиббсийн энергийн хамгийн бага утгын үеийн тэнцвэрийн тогтмолыг тооцоолов. Ингэхдээ доор үзүүлсэн томъёонуудыг ашиглан хийжүүлэлтийн үеийн температур $350-1500^{\circ} \mathrm{C}$ байхад урвалд орох болон түүнээс гарах бүтээгдэхүүний дулаан багтаамжуудыг температурын утга болгон авч, улмаар даралт тогтмол үеийн дундаж дулаан багтаамжийг тооцон түүнээс хамааруулан Гибссийн энергийн хэмжээг тодорхойлон тэнцвэрийн тогтмолын утгыг гаргасан болно.
Тооцоонд зарим нэг хэмжигдэхүүнүүдийг ижил нөхцөлд буюу техникийн хэвийн нөхцөлд тооцож байгаа гэдгээр нь тусгайлсан хүснэгтүүдээс шууд авч ашигласан. Тухайлбал, нүүрстөрөгчийн диоксид $\left(\mathrm{CO}_{2}\right), \quad$ нүүрстөрөгчийн моноксид (CO), усны уур $\left(\mathrm{H}_{2} \mathrm{O}\right)$, устөрөгч $\left(\mathrm{H}_{2}\right)$-ийн температураас хамаарсан дулаан багтаамжийн тэгшитгэлийн коэффициентүүдийн алгебр нийлбэр, 298 К температурын үеийн дулаан агуулалт, энтропи зэргийг тооцоонд хүснэгтүүдээс авч хэрэглэв [10].

\begin{tabular}{|c|c|c|c|c|c|c|c|}
\hline \multirow{2}{*}{ Хийн нэр } & \multirow{2}{*}{$\begin{array}{c}\text { Тэмдэг- } \\
\text { лэгээ }\end{array}$} & \multirow{2}{*}{$\begin{array}{c}\Delta_{\mathrm{r}} \mathrm{H}^{0}{ }_{298} \\
\text { кДж/ } \\
\text { моль }\end{array}$} & \multirow{2}{*}{$\begin{array}{c}\Delta_{\mathrm{r}} \mathrm{S}^{0}{ }_{298}, \\
\text { кДж/ } \\
\text { мольК }\end{array}$} & \multicolumn{3}{|c|}{$\begin{array}{c}\mathrm{C}_{\mathrm{p}}^{0}=\mathrm{f}(\mathrm{T}) \text { тэгшитгэлийн } \\
\text { коэффициент, Дж/мольК }\end{array}$} & \multirow{2}{*}{$\begin{array}{c}\text { Температурын } \\
\text { зайц, }{ }^{\circ} \mathrm{K}\end{array}$} \\
\hline & & & & a & B & $\mathrm{c}$ & \\
\hline Нүүрстөрөгчийн диоксид & $\mathrm{CO}_{2}$ & -393.51 & 213.66 & 44.14 & 0.00904 & -854000 & $298-2500$ \\
\hline Нүүрстөрөгчийн моноксид & $\mathrm{CO}$ & -110.5 & 197.55 & 28.41 & 0.0041 & -46000 & $298-2500$ \\
\hline Усны уур & $\mathrm{H}_{2} \mathrm{O}$ & -241.84 & 188.72 & 30 & 0.01071 & -33000 & $298-2500$ \\
\hline Устөрөгч & $\mathrm{H}_{2}$ & 0 & 130.52 & 27.28 & 0.00326 & 50200 & - \\
\hline
\end{tabular}

ХУснэгт 1. Тооионд ашигласан хийн стандарт утгууд 
Даралт тогтмол үеийн дулаан багтаамжийг 1-р хүснэгтэнд үзүүлсэн тэгшитгэлийн коэффициентүүдийг ашиглан өгөгдсөн температурын нөхцөлд дараaх томъёогоор тодорхойлов.

$$
C p=a+b T+c T^{2}
$$

Харин 298 К температурын үеийн Гибссийн энергийн утгыг мөн хүснэгтэнд үзүүлсэн хийн дулаан агуулалт, энтропийн утгаар дараах томъёогоор тооцов.

$$
\Delta G_{298}^{0}=H_{298}^{0}+298 \cdot \Delta S_{298}^{0}
$$

Өгөгдсөн температурын үеийн Гибссийн энергийн хэмжээг доорхи томъёогоор тооцож, улмаар урвалын тэнцвэрийн тогтмолыг тодорхойлон 2-р зурагт үзүүллээ.

$$
\begin{aligned}
& \Delta G_{298}^{T}=\Delta r H_{T}^{0}+T \cdot \Delta r S_{T}^{0} \\
& \Delta G_{298}^{T}=-R T \ln K_{p}=>\ln K_{p}=\frac{\Delta G_{298}^{T}}{R T}
\end{aligned}
$$

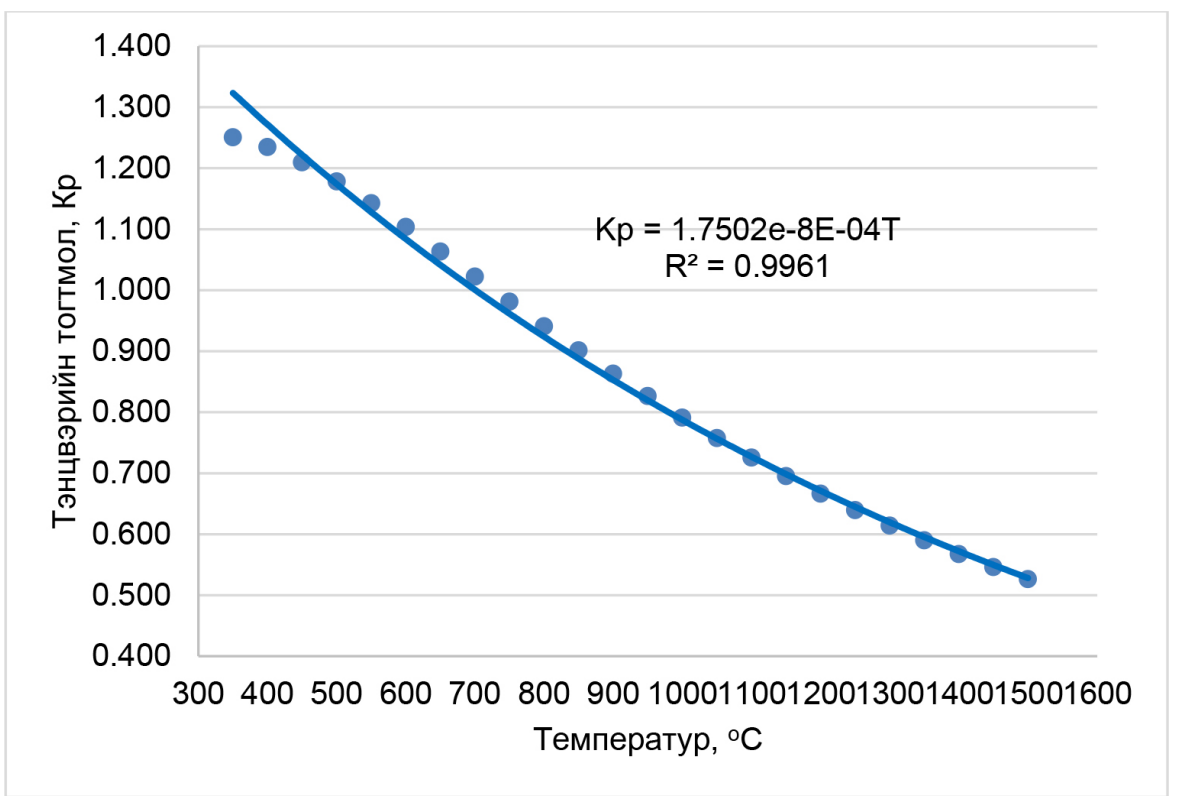

Зураг 2. Температур ба тэнцвэрийн тогтмольн хоорондын хамаарал

Дээрх зургаас харахад температурын утга нэмэгдэх тутам урвалын тэнцвэрийн тогтмол буурч байгаа ба тэдгээрийн хоорондын хамаарал нь $\mathrm{Kp}=1.7502 * \mathrm{e}^{-8 * 10^{\wedge}}$ $4^{*} \mathrm{~T}, \mathrm{R}^{2}=0.9961$ байна. Өөрөөр хэлбэл энэ тооцооны үр дүн нь Гибссийн энергийн утга багассаар тэг хүрэхэд урвал тэнцвэрт ордог гэсэн онолын ойлголтыг батлаж байгаа юм.

Тооцоогоор гаргасан тэгшитгэлд бодит утга буюу туршилтын температурын утгыг орлуулан тооцож үзэхэд онолын утгаас дараах зөрүүтэй буюу алдааны дундаж нь 19.7\%-иар зөрж байгааг дараах зургаас харж болно. 


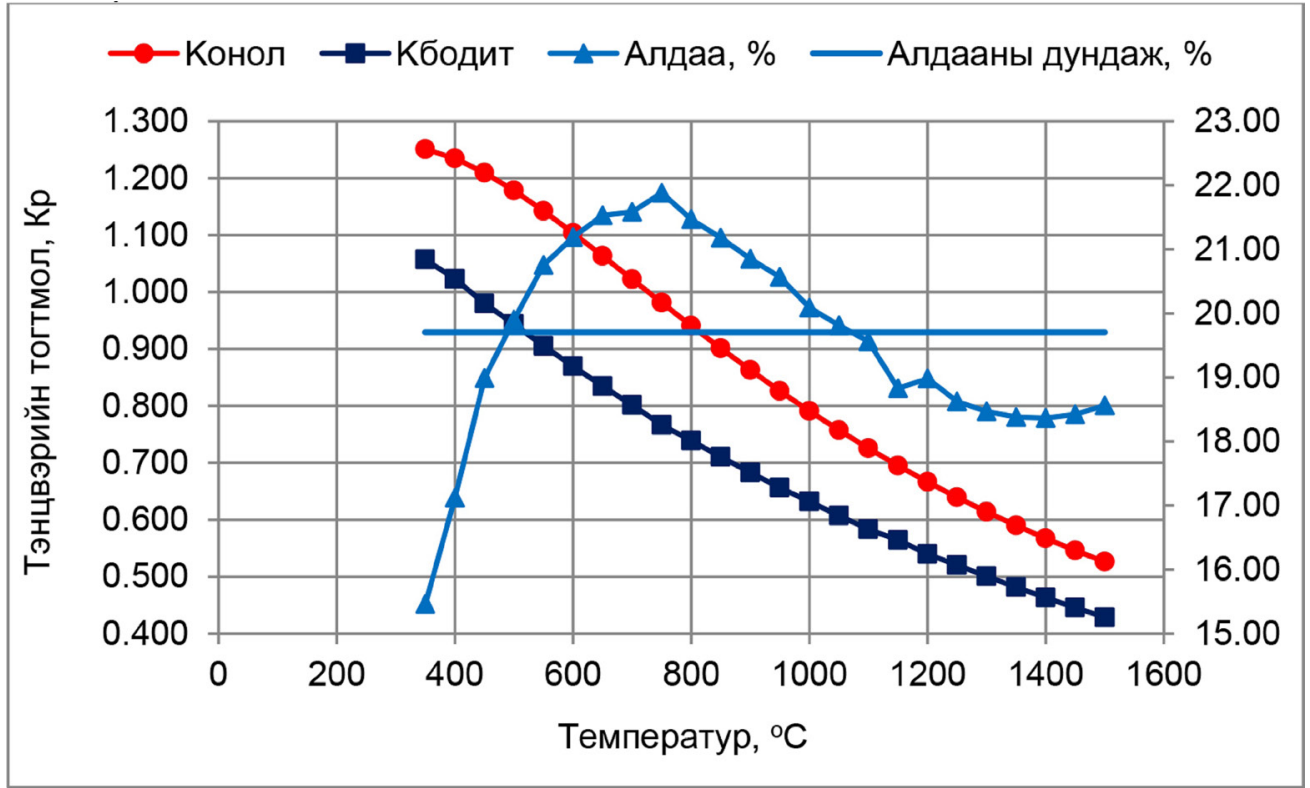

Зураг 3. Гибссийн энергийн аргаар тооисон тэнияврийн тогтмол ба температурын хамаарал

Хийжүүлэлтийн үндсэн урвал болох $\mathrm{CO}+\mathrm{H}_{2} \mathrm{O} \Leftrightarrow \mathrm{CO}_{2}+\mathrm{H}_{2}$ дээр бичсэн $\log K_{P}=-36.72508-\frac{3994.704}{T}-4.462408 \cdot 10^{-3} T+0.671814 \cdot 10^{-6} T^{2}+12.220277 \cdot \log T$ логарифм тэгшитгэлээр тэнцвэрийн тогтмолыг тооцлоо.

Энэ аргаар тооцсон тэнцвэрийн тогтмол ба температурын хоорондын хамаарал болон бодит, онолын утгуудын хоорондын зөрүү, тооцооны алдааг тооцсон үр дүнг 4-р зурагт үзүүлэв.

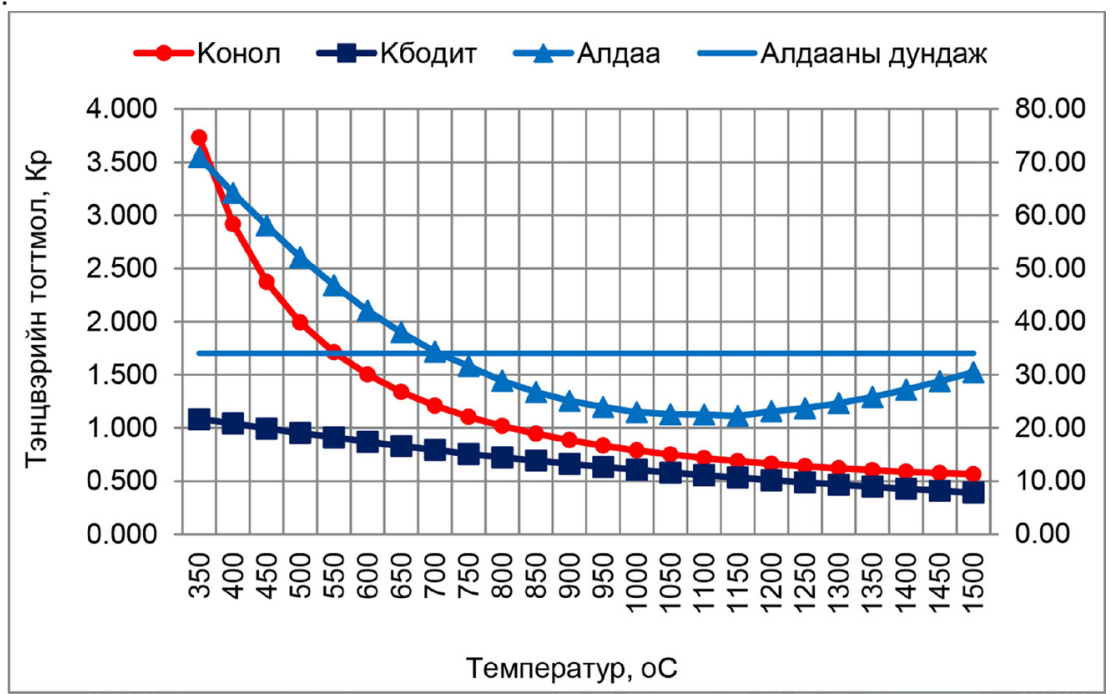

Зураг 4. Логарифм тэгшитгэлээр тооисон тэниявэрийн тогтмол ба температурын хамаарал 
Дээрх зургаас тооцоход онолын ба бодит утга ихээхэн зөрүүтэй буюу алдааны дундаж утга нь $34.05 \%$ байна.

Логарифмийн болон Гибссийн энергийн аргаар тооцсон тэнцвэрийн тогтмолын утгыг харьцуулахад алдааны дундаж утга 14.64\% байгаa ба үүнийг 5-р зурагт үзүүллээ.

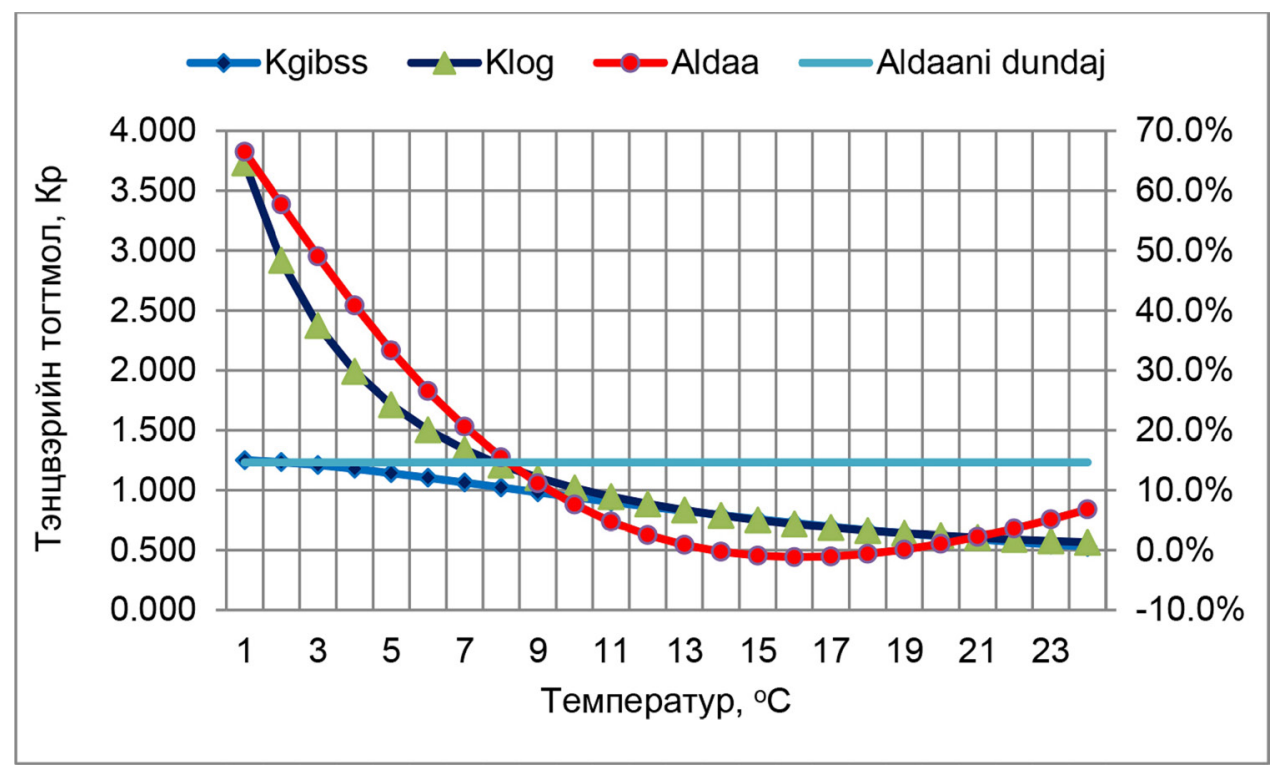

Зураг 5. Гибссийн ба Логарифмийн аргаар тооисон тэнивъэрийн тогтмольн харьиуулалт

\section{ДУГНЭЛТ}

Гибссийн энергийн аргаар тэнцвэрийн тогтмолыг тооцоход онолын ба бодит утгын зөрүу дундажаар 19.7\%, логарифм аргаар тооцоход алдааны дундаж утга $34.05 \%$ байна.

Гибссийн ба логарифм тэгшитгэлээр тооцох аргуудыг хооронд нь харьцуулахад температур нэмэгдэхэд тэнцвэрийн тогтмол буурна гэсэн онолын ойлголт нь батлагдаж байгаа бөгөөд хоёр аргын хоорондын зөрүҮ дундажаар $14.64 \%$ байна.

Эцэст нь дүгнэхэд Гибссийн энергийн арга нь илүҮ нарийвчлалтай, алдаа бага тул хийжүүлэлтийн тооцоонд ашиглахад тохиромжтой гэж үзлээ.

\section{НОМ ЗYЙ}

1. Г.Д. Харлампович,Химическая технология твердых горючих ископаемых. М.: Химия. 1986.-496., ил.

2. В.С. Альтшуллер. Новые процессы газификачии твердого топлива. М.: Недра, 1976.-200 c.

3. Г.Н. Сеченов, В.С. Альтиуллер. Газогенераторы для производства энергетических газов из твердого топлива // Газовые процессы. Получение энергетических и технологических газов. - М.: Наука, 1967. 41-49.

4. Wilhelm Gumz. Gas producers and Blast furnace. 1950

5. Г.И.Дешалит. Расчеты процессов газификаиий топлива 
6. Н.Г.Юдушкин. Газогенераторные тракторы. Москва. 1955

7. С.Д.Бесков. Техно-химические расчеты. Москва. 1962.

8. Л.П.Владимиров. Термодинамические расчеть равновесия металлургических реакиий. Издательство “Металлурия” Москва 1970.

9. Г.П.Духанин, В.А.Козловиев. Термодинамические расчеты химических реакиий. Учебное пособие. Волгоград. 2010.

10. Л.В.Цыро, С.Я.Александра. Физическая химия: Химическое равновесие. Учебнометодическое пособие. Томск. 2012. 


\title{
DETERMINATION OF EQUILIBRIUM CONSTANT OF THE COAL GASIFICATION REACTION
}

\author{
A. Tumenbayar ${ }^{1 *}$, B. Avid $^{2}$, Ch. Dashpuntsag ${ }^{1}$ \\ ${ }^{1}$ School of Power Engineering, Mongolian \\ University of Science and Technology \\ ${ }^{2}$ Mongolian Academy of Sciences \\ E-mail:tumee_79@must.edu.mn
}

Thermodynamic equilibrium modeling approach is widely used to evaluate the performance of gasification system in terms product gas composition and efficiency. Gibbs energy minimization and logarithm equation methods are applied in modelling the coal gasification process. The results show that the Gibbs energy minimization method is better for estimating equilibrium constant of the coal gasification process.

Keywords: Equilibrium constant of reaction, gasification, gas composition, temperature; 